\title{
A Széchenyi István Egyetem nemzetköziesítése a világjárvány elótt és után
}

\section{Internationalisation of Széchenyi István University before and after the Pandemic}

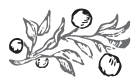

\section{Összefoglalás}

A tanulmány fő célja a Széchenyi István Egyetem példáján keresztül bemutatni, hogy milyen prioritásokat érdemes szem előtt tartania a hazai felsőoktatási intézményeknek - különösen a nem fővárosi, orvostudományi karral és kialakult nemzetközi hallgatói közösséggel (kolóniával) nem rendelkező egyetemeknek - a nemzetköziesítési folyamatuk során. A hazai felsőoktatási intézmények nemzetköziesítési stratégiájuk megfogalmazásakor a világgazdasági trendekkel összhangban a „keleti nyitás” gazdaságpolitikájához alkalmazkodtak, azaz angol nyelvű képzéseiken elsősorban az ázsiai - főként kínai - hallgatók toborzására összpontosítottak. Az ázsiai/kínai hallgatók megszerzéséért folyó verseny erősödése (többek között az ázsiai felsőoktatási intézmények látványos fejlődése miatt) és az Ázsiából/Kínából származó hallgatók számának pandémia utáni anticipált csökkenése - a nemzetköziesítési folyamataikban - kihívások elé állítja a hazai felsőoktatási intézményeket, különösen azok fentebb említett csoportját, amelybe a Széchenyi István Egyetem is tartozik. A győri Egyetem a nemzetközi felsőoktatási rangsorokon történő megjelenés és feljebb jutás, a branding (kiemelkedő ipari kapcsolatok), a képzések nemzetközi akkreditációja és impozáns, grandiózus infrastrukturális beruházások révén törekszik a kihívásokra választ adni.

Dr. Filep BÁLint PhD, elnök, Széchenyi István Egyetem, Győr (filep.balint@sze. hu), Dr. Lukács EszTer PHD, oktatási rektorhelyettes, egyetemi docens, Széchenyi István Egyetem, Győr (lukacs.eszter@sze.hu). 
Journal of Economic Literature (JEL) kódok: I21, I23

Kulcsszavak: nemzetközi hallgatói mobilitás, ázsiai/kínai hallgatók, magyar felsőoktatás nemzetköziesítése, Széchenyi István Egyetem, Győr

\section{Summary}

The main aim of the study is to present, through the example of Széchenyi István University, the priorities that Hungarian higher education institutions - especially universities based outside the capital without a medical faculty and an established international student community - should keep in mind during their internationalization process. In the formulation of their internationalization strategies, in line with global economic trends, Hungarian higher education institutions have adapted to the economic policy "Opening to the East", that is they have focussed primarily on the recruitment of Asian - primarily Chinese - students to their English-taught programmes. The intensification of competition to recruit Asian/ Chinese students (due in part to the spectacular development of Asian higher education institutions) and the anticipated decline in the number of Asian/Chinese students following the pandemic pose challenges for Hungarian higher education institutions - especially the above-mentioned group, to which Széchenyi István University also belongs - in their internationalization processes,. The University of Györ strives to meet such challenges through its presence and advancement on international higher education rankings, via branding (outstanding industrial relations), the international accreditation of its academic programmes and impressive and ambitious infrastructure investments.

Journal of Economic Literature (JEL) codes: I21, I23

Keywords: international student mobility, Asian/Chinese students, internationalisation of Hungarian higher education, Széchenyi István University, Győr

\section{BeVEZETÉS}

A tekintélyes angol hetilap, a The Economist 2020 augusztusában megjelent cikke („A hiányzó hallgató") a jelenlegi Covid-19 járvány (angolszász) egyetemekre gyakorolt negatív hatásaival foglalkozik, ugyanakkor azt is felveti, hogy a pandémia régóta szükséges változásokat is magával hozhat az egyetemek életében. A világjárvány megállította a tanulmányi célú migrációt és a külföldi hallgatók kiesése miatt az egyetemek jelentős bevételtől estek el, valamint múködésük teljeskörủ átszervezésére kényszerültek. Ugyanakkor a cikk a világjárvány pozitív következményeként szól arról a lehetőségről, hogy az egyetemek a kormányok által támasztott kritériumoknak (megfelelő oktatás és kutatás, amely a piaci elvárásokat figyelembe veszi, hozzájárul a termelékenység növeléséhez) a jövőben jobban igyekeznek megfelelni, mivel a válság miatt nőni fog a kormányzattól való függőségük. Azon egyetemek, amelyek nem felelnek meg a kormányok kritériumainak, azaz nem kínálnak megfelelő oktatást, kutatást és nem járulnak hozzá a közösségük jólétéhez, bukásra vannak itélve. A túlélő egyetemeknek pedig le 
kell vonniuk a pandémiás időszak tanulságait és ezekre reagálva kell meghozniuk a szükséges változásokat (The Economist, 2020).

Jelen tanulmány a nemzetköziesítés útjára viszonylag későn lépő magyar egyetem, a győri Széchenyi István Egyetem világjárvány utáni nemzetköziesítési prioritásaival foglalkozik. A Széchenyi István Egyetem a hagyományos képzési és tudományos területei mellett kiemelt fókuszba helyezte a nemzetközi terület komplex fejlesztését. A világjárvány előtt és alatt az angol nyelvű képzések száma harmincnégyre növekedett, a nemzetközi hallgatói létszám pedig megötszöröződött. Az egyetem vezetése a nemzetköziesítésre, azaz az angol nyelven történő oktatási és kutatási tevékenységre a globális láthatóság eszközeként tekint, amelyek kiegészítik a szintén világgazdasági környezetben is egyedülállóan sikeres harmadik missziós tevékenységét. Az egyetem a válság után megváltozott környezetben nagyságrendileg 25.300 felsőoktatási intézménnyel versenyez a magyar és nemzetközi hallgatókért. Utóbbiak a diplomára és a külföldön való felsőfokú tanulmányok folytatására megtérülő befektetésként tekintenek, így az egyetemek azokat a küldő országokat célozzák meg hallgató toborzó tevékenységükkel, ahol a felsőoktatásba történő befektetésre a legnagyobb hajlandóság mutatkozik, amivel párhuzamosan azt igyekeznek feltárni, hogy milyen motivációk mentén választják a nemzetközi mobilitásban résztvevő hallgatók (és családjaik) az egyes egyetemeket. Mivel az elmúlt évtized világgazdasági növekményének felét Kelet-, Délkelet- és Dél-Ázsia országai mutatták fel, így szinte minden nemzetköziesítéssel foglalkozó felsőoktatási intézmény rendelkezik „Ázsia-, ezen belül specifikusan Kína-stratégiával.” Tanulmányunk fő célja a Széchenyi István Egyetem pandémia utáni, gyorsan változó felsőoktatási környezetben való nemzetköziesítési prioritásainak ismertetése.

A tanulmány első részében röviden felvázoljuk az egyetem modellváltását és a globális trendekhez igazodó, 2016 és 2020 közötti nemzetköziesítési folyamatát. A második rész foglalkozik a világ legnagyobb nemzetközi hallgató kibocsátó régiójával és országával, Ázsiával, illetve Kínával. Vizsgáljuk az ázsiai/kínai hallgatók mobilitását és az arra ható, toló- és húzótényezőket. Kiemelt figyelmet fordítunk az ázsiai/kínai hallgatók magyar felsőoktatási intézményekben való megjelenésére, illetve az ázsiai/kínai hallgatók vonzásáért folytatott globális verseny erősödésére és a kínai hallgatók pandémia utáni intézményi választásaira. A harmadik részben bemutatjuk, hogy hogyan és milyen válaszokat kíván adni a Széchenyi István Egyetem a nemzetköziesítés folyamatában a második fejezetben bemutatott ázsiai/kínai hallgatók vonzásában megmutatkozó kihívásokra. Végül a tanulmányunkat összegzéssel zárjuk.

\section{A SZÉCHENYI ISTVÁN EGYETEM NEMZETKÖZIESÍtéSI FOLYAMATAI}

\section{A modellváltás}

Nyugat-Európában, az 1990-es években jelentős változások kezdődtek a felsőoktatás-irányításban és ezzel összefüggésben az egyetemi kormányzásban is. A felsőoktatás-irányításban az állami kontroll csökkenésével párhuzamosan az egyetemi kormányzásban a tradicionális kollegiális vezetést felváltotta a menedzserizmus, és az utóbbi időben pedig - ebben a vonatkozásban - inkább útkeresésről, illetve finomhangolásról lehet beszélni (Keczer, 2020). „Az 
útkeresés a felsőoktatás-irányításban (rendszerszinten) többek között kiterjed az intézmények státusára (például alapítványi forma), finanszírozására (a gazdálkodási önállóság növelése, illetve csökkentése), a szabályozás diverzifikációjára (bizonyos intézmények kiemelt státusa), az egyetemi alkalmazottak foglalkoztatására (közalkalmazotti státus megszüntetése), és az akkreditációra (intézményi akkreditáció, nemzetközi auditorok)" (Keczer 2020:60). Az egyetemi kormányzás legújabb trendjeiről Pruvot és Estermann (2018) 20 európai országban végzett vizsgálata alapján a következőket állapította meg: Az egyetemi kormányzás két modellje különíthető el: unitárius és duális. Ez utóbbin belül megkülönböztethető a tradicionális és aszimmetrikus kormányzási modell. Az unitárius modell olyan kormányzási struktúra, amelyben csak egy irányító testületnek van döntési jogköre, amely szenátus vagy igazgatótanács (board) jellegű lehet. A vizsgált 20 országból 9 ország egyetemi irányítására jellemző az unitárius modell, amelyből 6 esetében board jellegü testület hozza a döntéseket. A duális modell olyan kormányzási struktúra, amelyben a szenátus és board típusú testületek megosztják egymás között a döntési jogköröket. A tradicionális duális modellben mindkét testületnek megkülönböztetett, de egyformán fontos kötelezettségeik vannak. Mindazonáltal ugyanazon kérdésekben együtt dönthetnek. Az aszimmetrikus duális modellben jelen van a szenátus és a board típusú testület is, de közülük az egyiknek központi szerepe van a döntéshozatali folyamatban. Jellemzően a board típusú testületek dominánsak ebben a modellben. Összességében Pruvot és Estermann (2018) megállapítják, hogy az európai egyetemek kormányzásában a board típusú testületek egyre elterjedtebbek és befolyásuk a döntési folyamatokban növekvő.

A magyar felsőoktatás közelmúltban bekövetkezett és jelenleg is folyamatban lévő változása, vagyis ,,a kancellári és konzisztóriumi rendszer bevezetése, az állami intézmények közalapítványi formába történő átszervezése és magánintézménnyé alakítása (modellváltás) mind a működés professzionalizálásának, a hatékonyság, a teljesítmény, a kiválóság, a versenyképesség, a szolgáltató szemlélet javításának jegyében történik. Ezek pontosan azok a célok, amelyek mentén a felsőoktatás átszervezése Angliában, Hollandiában és más nyugati országokban is zajlott” (Kováts 2020:5), amelynek finomhangolása - a fentebb leírtak alapján - jelenleg is folyamatban van.

A magyar kormány 2014-ben elfogadott „Fokozatváltás a felsőoktatásban” című stratégiájában megfogalmazott célja a felsőoktatás új, fenntartható pályára állítása, a meglévő szabályozási és működési keretek átalakításával. A Széchenyi István Egyetem az elmúlt évtizedekben a térség és Magyarország egyik meghatározó felsőoktatási intézményévé vált, számottevően növelte hallgatói létszámát és saját bevételeit, fejlesztette infrastruktúráját, kiemelkedő likviditása pedig stabilitást nyújtott. Mindezek biztos alapot jelentenek ahhoz, hogy az Egyetem a modellváltás által kínált megújulási lehetőség nyertese lehessen. 2020. augusztus 1-jén a Széchenyi István Egyetem fenntartói jogait az államtól a Széchenyi István Egyetemért Alapítvány vette át. Az Alapítvány, mint fenntartó feladata és felelőssége a Kuratórium tagjaival és az egyetemi közösséggel karöltve az eddiginél is rugalmasabb, kiszámíthatóbb, tervezhetőbb működési környezet megteremtése, az Egyetem nemzetközi versenyképességének erősítése.

Az állam által elismert vagyonkezelői alapítvány a fenntartói lehetőségek széles körét nyitotta meg. Az oktatói-kutatói-tudományos autonómia megmaradt. A történelmi magyaror- 
szági folyamat alapján, változatlanul a rendszerváltás óta. Új lehetőségek nyíltak viszont a fenntarthatóság és gazdálkodás területén, amely valósabb függetlenséget jelent az egyetemi közösségek számára, biztos anyagi hátteret, új funkciókat és éven túli gazdálkodást. A fenntartóváltástól a Széchenyi István Egyetem hatékonyabb és rugalmasabb működést, újabb fejlesztéseket, a partnerkapcsolatok és szolgáltatóképességének erősödését várja. A modellváltást követően az Egyetem célja, hogy az új működési-gazdálkodási feltételek között képessé váljon önálló stratégia alapján a céljai eléréséhez szükséges forrásokat megteremteni és hatékonyan felhasználni. A rugalmasabb gazdasági körülmények lehetővé teszik, hogy az egyetem nagyobb gazdasági önállósággal, tágabb mozgástérben fogalmazza és valósítsa meg célkitűzéseit, feladatait (Széchenyi István Egyetem, 2020a).

\section{A Széchenyi István Egyetem nemzetköziesitésének helyzetértékelése}

A Széchenyi István Egyetemért Alapítvány Kuratóriuma a 2020. december 10-i ülésén fogadta el a felsőoktatási intézmény nemzetköziesítési helyzetértékelését és globális láthatósági stratégiájára vonatkozó irányelveit. Az Egyetem a nemzetköziesítés, ezen belül a nemzetközi oktatás területén a minőségi felsőoktatás megvalósítására törekszik, a világ nagyságrendileg 25.300 egyeteme között versenyez egymással és a hallgatókért. A Széchenyi István Egyetem 2020-ig, a „Fokozatváltás a felsőoktatásban” elnevezésű felsőoktatási stratégiához illeszkedve a tudásnégyszög (quadruple helix) modelljében végezte tevékenységét. A tudásnégyszög, azaz egyetem-ipar-kormányzat-civil szféra/egyházak/média kapcsolatrendszer a Széchenyi István Egyetemet fenntartó alapítvány kuratóriumának összetételében is megmutatkozik. A kuratórium tagjai:

- Knáb Erzsébet, kuratóriumi elnök, az Audi Hungaria Zrt. személyügyért és szervezetért felelős igazgatósági tagja,

- Szijjártó Péter, külgazdasági és külügyminiszter,

- Dézsi Csaba András, Győr Megyei Jogú Város polgármestere,

- Bokor József, a Magyar Tudományos Akadémia rendes tagja, az egyetem Járműipari Kutatóközpontjának elnöke

- Sárai-Szabó Tamás Kelemen, a győri Szent Mór Bencés Perjelség perjele.

Új, a 2021-es évtől megvalósításra váró globális láthatósági stratégiájában a felsőoktatási intézmény már a tudásötszög (quintuple innovation helix) modelljére épít, amiben a felsorolt négy szöget kiegészíti, a természeti környezettel való harmóniában való együttélést, a fenntartható fejlődés szempontjait veszi figyelembe. Ez utóbbi megmutatkozik az Innovációs és Technológiai Minisztérium (ITM) 2030-ig felvázolt gazdaságstratégiájában, amihez a Széchenyi István Egyetem 2021-ben megfogalmazásra kerülő új Intézményfejlesztési Terve is illeszkedik, továbbá a fenntarthatóság alapelveinek integrálását a két monopolhelyzetben lévő minősítő intézmény egyike, a Times Higher Education (THE) az Impact Rankings elnevezésű listáján, az ENSZ tizenhét Fenntartható Fejlődési Célja mentén is méri.

Carayannis et al. (2012) amellett foglaltak állást, hogy a 21. században az innováció hajtóereje a globális felmelegedés lesz, így a társadalom öt alrendszere (az oktatási rendszer, a gazdasági rendszer, a természeti környezet, a médiára és kultúrára épülő civil társadalom, 
illetve a politikai rendszer) együttműködésben kell, hogy megoldásokat találjon.

\section{1. ábra: A Quintuple Helix modell alrendszerei}

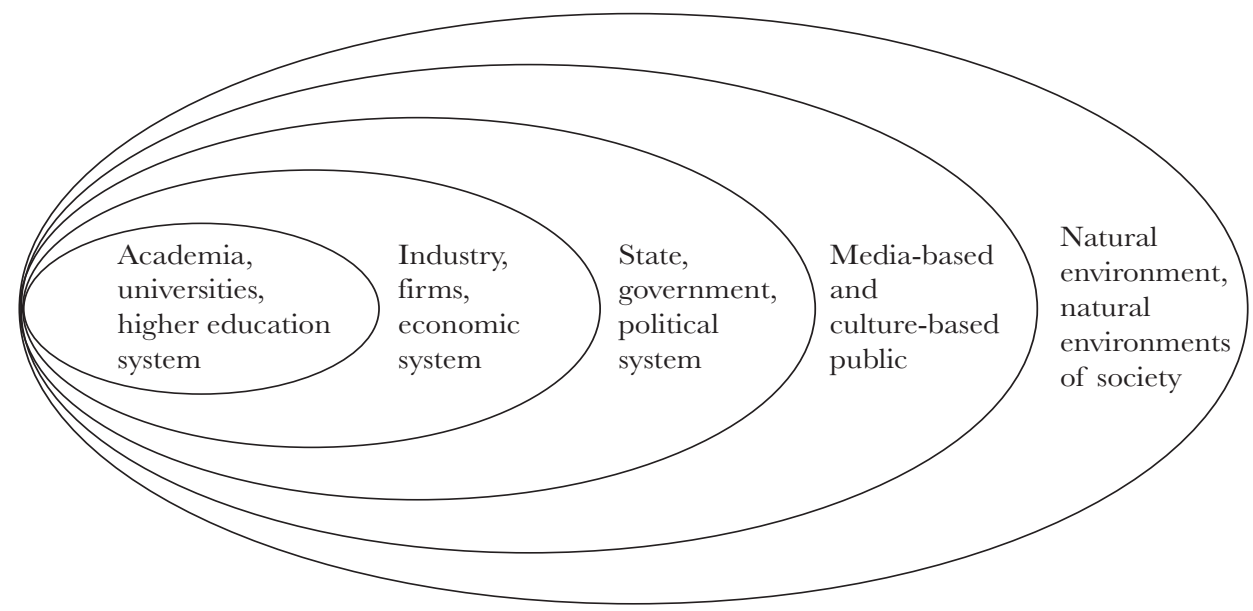

Forrás: Carayannis et al. (2012:6)

A Széchenyi István Egyetem, a 2016-2020 között hatályban lévő Intézményfejlesztési Tervében a Fokozatváltás a felsőoktatásban szakpolitikai stratégiával összhangban

- az angol nyelvű képzések bevezetését,

- a nemzetközi hallgatók vonzását,

- az Erasmus+ programban résztvevő hallgatók számának növelését,

- a külföldi oktatók nemzetközi képzési programokba történő bevonását és

- az oktatók, valamint az adminisztratív munkatársak angol nyelvi kompetenciáinak fejlesztését tűzte ki elsődleges nemzetköziesítési céljaiként.

2016-ban az Intézményfejlesztési Terv megfogalmazásakor az egyetem két angol nyelvű programmal rendelkezett, amit további néggyel, összesen hatra tervezett emelni. Az angol nyelven oktatott szakok számára és a nemzetközi hallgatói létszámra vonatkozóan az Egyetem az 1. táblázat szerinti eredményeket érte el.

\section{Nemzetközi hallgatók és angol nyelvü képzések számának növekedése}

A nemzetközi hallgatók jelenleg a teljes hallgatói létszám 4,55 százalékát teszik ki. Cél, hogy ez az arány 10-15 százalékra emelkedjen. A hallgatói létszám növelése elképzelhetetlen az angol nyelvű képzési kínálat növelése nélkül. 2020-ra mind a műszaki (elsősorban járműmérnöki) és gazdasági képzések területén megvalósult a teljes képzési vertikum, azaz a nemzetközi (és angolul tanulni kívánó magyar) hallgatók az alapképzésektől a doktori fokozatszerzésig, 
Filep Bálint-Lukács Eszter: A Széchenyi István Egyetem nemzetköziesitése a világjárvány ...

egymásra épülő képzési programokon tudták tanulmányaikat folytatni.

1. táblázat: A nemzetközi hallgatók és angol nyelvü szakok száma

\begin{tabular}{|c|c|c|c|c|c|c|c|c|}
\hline Mutató/tanév & $\begin{array}{r}2013 \\
/ 14\end{array}$ & $\begin{array}{l}2014 \\
/ 15\end{array}$ & $\begin{array}{c}2015 \\
/ 16\end{array}$ & $\begin{array}{l}2016 \\
/ 17\end{array}$ & $\begin{array}{l}2017 \\
/ 18\end{array}$ & $\begin{array}{l}2018 \\
/ 19\end{array}$ & $\begin{array}{l}2019 \\
/ 20\end{array}$ & $\begin{array}{c}2020 \\
/ 21\end{array}$ \\
\hline Teljes hallgatói létszám & 10668 & 10540 & 10429 & 12743 & 12281 & 12189 & 13821 & 13482 \\
\hline $\begin{array}{l}\text { Nappali tagozatos } \\
\text { hallgatók }\end{array}$ & 7355 & 7217 & 6953 & 8198 & 7774 & 7616 & 8277 & 8135 \\
\hline $\begin{array}{l}\text { Nemzetközi hallgatók } \\
\text { (beleértve a magyar } \\
\text { nemzetiséggel } \\
\text { rendelkezőket) }\end{array}$ & 399 & 337 & 336 & 409 & 440 & 475 & 558 & 614 \\
\hline Nemzetközi hallgatók & 33 & 52 & 64 & 58 & 142 & 199 & 283 & 335 \\
\hline Angol nyelvű programok & 0 & 0 & 2 & 5 & 5 & 7 & 24 & 34 \\
\hline
\end{tabular}

Forrás: Lukács (2020)

A Széchenyi István Egyetem a 2020/21-es tanévet összesen 13.482 hallgatóval kezdte meg, akik közül 8.135-en iratkoztak be nappali képzésre. A nem magyar állampolgárságú, de magyar nemzetiségű hallgatókat figyelembe véve a teljes nemzetközi hallgatói létszám 614 fő volt, a nem magyar állampolgárságú és nem magyar nemzetiségű hallgatói létszám pedig 335 fő volt. Utóbbi hallgatók a 133 angol nyelvü képzésre felvett magyar állampolgárságú és magyar nemzetiségű hallgatóval együtt 34 képzés közül választhattak. (Az egyetem által kínált magyar nyelvű programok száma 205 volt.)

A világ felsőoktatási intézményei a nemzetközi hallgatók jelenlétére több oknál fogva építenek. A nemzetközi hallgatók sokszor jelentős bevételeket jelentenek az egyetemek számára, másrészt a fejlett országok kedvezőtlen demográfiai trendjeit is hivatottak kompenzálni, nem utolsó sorban pedig a világ- és regionális rangsorok összeállításánál mindkét prominens minősítő intézmény (a Times Higher Education (THE) és a Quacquarelli Symonds (QS)) figyelembe veszi a nemzetközi hallgatók teljes intézményes hallgatói létszámra vetített arányát.

A fent felsorolt szempontok közül az utolsót a Széchenyi István Egyetem is szem előtt tartja, a nemzetközi hallgató toborzási folyamat során azonban sem a bevételek megszerzése, sem a demográfiai csökkenés nem tartozik az elsődleges motivációk közé. Mint minden felsőoktatási intézmény, különösen a modellváltó egyetemek, a Széchenyi István Egyetem is törekszik a különböző forrásokból való bevételek maximalizálására, ugyanakkor a nemzetközi hallgatók önköltségei vagy az államilag támogatott külföldi hallgatók képzéséből származó források az egyetem teljes költségvetését sokkal inkább kiegészítik, mint alapjaiban meghatározzák azt.

A Széchenyi István Egyetem esetében a nemzetközi hallgatók fogadása, ennek előfeltételeként az angol nyelvű képzési programok számának növelése, a minőségi felsőoktatás záloga. Az angol nyelven történő oktatási tevékenység további előfeltételként követeli meg a szintén idegen (elsősorban angol) nyelven véghezvitt kutatási folyamatokat, ill. az eredmények publikációját. A nemzetköziesítés (nemzetközi hallgatók toborzása és angol nyelvü képzési 
programok indítása) tehát „kvázi rákényszeríti” az egyetemeket, hogy első két missziójukat, az oktatást és a kutatást globális térben, nemzetközi színtéren megmérettetve folytassák. A gazdasági tevékenységek folytatása, az iparral (multinacionális vállalatokkal, globális értékláncokkal) való kapcsolattartás, azaz a harmadik missziós feladatkörök a Széchenyi István Egyetem esetében tovább támogatják a nemzetköziesítés folyamatát.

Fentiek alapján belátható, hogy a nemzetköziesítés folyamata a globális láthatóság megteremtésének eszköze. Szintén a fentiekből fakad az a kérdés, hogy honnan és hogyan toboroznak az egyetemek nemzetközi hallgatókat? Mik a földrajzi prioritások? Milyen tényezők támogatják, ill. akadályozzák a külföldi hallgatók vonzását? Lukács et al. (2020) megállapítják, hogy a világ legnagyobb nemzetközi hallgató kibocsátó régiói Kelet-, Dél- és Délkelet-Ázsia, ezeken belül pedig Kína, India és a magas HDI-vel rendelkező ASEAN országok jelentik a teljes idős képzésekre érkező nemzetközi hallgatók legjelentősebb forrását. Szintén megállapítják, hogy a magyar „keleti nyitás gazdaságpolitikája” keretében elindított, jelenleg már közel 80 országgal fenntartott, bilaterális, de reciprocitás nélküli felsőoktatási program (Stipendium Hungaricum, SH), amelynek keretében Magyarország Kormánya átvállalja a támogatott hallgatók képzési önköltségét, nagyban támogatja a fenti régiókból érkező hallgatók létszámának növekedését, különösen a nem fővárosi, orvostudományi karral és kialakult nemzetközi hallgatói közösséggel (kolóniával) nem rendelkező egyetemeken. Az SH program általánosan is rendkívüli ösztönző hatást gyakorol a magyar felsőoktatás nemzetköziesítésének egészére, hiszen Magyarországon az angol nem hivatalos és nem anyanyelv, a nemzetközi hallgatók fele pedig angol anyanyelvű célországot választ. További megállapításuk, hogy a nemzetközi hallgatókra az őket befogadó városok imázsa is nagymértékben hat, a külföldi hallgatók egyetemválasztási toplistájának felét rendszerint fővárosok uralják.

Fentiek alapján belátható továbbá, hogy a Széchenyi István Egyetem nemzetköziesítése a 2015/16-os tanévben két SH által támogatott képzési programmal indult, ami a 2020/21-es tanévre összesen 34 képzésre bővült, amik közül 25 élvezte az SH támogatását. A nemzetközi hallgatók összetétele is visszatükrözi a fenti folyamatokat: az egyetem 335 hallgatójának 85 százaléka SH támogatott, további 2 százalék szintén a Magyarország Kormánya által kezdeményezett bilaterális, viszonyosság nélküli támogatási rendszer, az Ösztöndíjprogram Keresztény Fiataloknak keretében érkezett.

A Széchenyi István Egyetem nemzetközi hallgatói összlétszáma (beleértve a magyar nemzetiségű, de nem magyar állampolgárságú hallgatókat) a fentebb említett 614 fő. A nemzetközi hallgatók 55 küldő országból érkeznek, hozzávetőlegesen 40 százalékuk felvidéki magyar, ugyanakkor az SH programnak köszönhetően más országokból is kezdenek kialakulni hallgatói közösségek, csoportok, amik közül a legnagyobb számosságúak az alábbiak: Szíria, Jordánia, Laosz, Azerbajdzsán, Kazahsztán, India, Kína. A Széchenyi Egyetem hallgatói létszámban mért SH rangsora szinte teljes átfedésben van az országos adatokkal, azzal a különbséggel, hogy az összesített magyar adatokat áttekintve, a küldő országok listáján Mongólia és Tunézia háttrébb szorítják Kazahsztánt. 
2. ábra: Nemzetközi hallgatók megoszlása a finanszírozás szerint

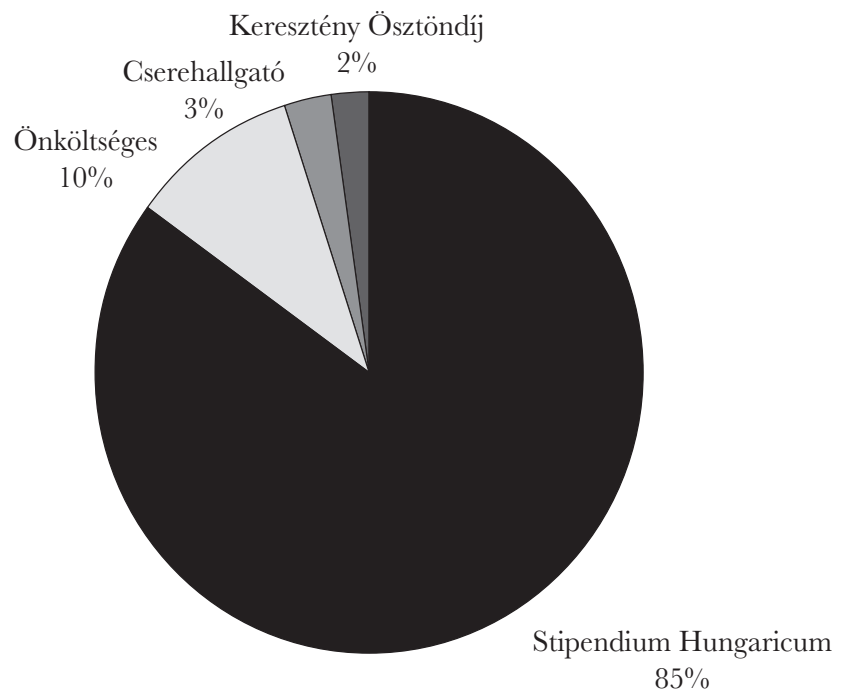

Forrás: Lukács (2020)

A Széchenyi István Egyetemen a Stipendium Hungaricum Program alapján 2015/16ban bevezetett, két képzési programra épített nemzetköziesítési folyamat gyors bővülésnek indult. A fent leírtak alapján, az SH új pályázati köreiben a szakfelelősök kezdeményezték az általuk gondozott képzési programok SH program általi támogatását, így az SH támogatott szakok száma 2015 és 2020 között 2-ről 5-re, 21-re, majd 25-re bővült. A nemzetköziesítés folyamata 2018-ban kapott új lendületet, amikor az SH programra történő további erőteljes építés mellett a győri Egyetem elkezdett önköltséges hallgatókat toborozni.

Az önköltséges hallgatók toborzását az egyetemi webfelületeken túl 39 toborzó ügynök segítségével végzi az egyetem, melyek közül 7 kínai, 6 pedig indiai vállalkozás. Az ügynökök toborzási tevékenységének eredményeként a Széchenyi István Egyetem 18 országból vonzott sikeresen önköltséges hallgatókat, akik 2020-ban a nemzetközi hallgatói állomány 10 százalékát tették ki. Az SH program sikere (multiplikatív hatása) itt is „visszaköszön”, 8,9 SH-s hallgató már három év után ,generál” egy SH származási országból felvett önköltséges hallgatót.

A világgazdasági növekedési trendeket továbbra is figyelembe véve a Széchenyi István Egyetem fő toborzási világrégiói Kelet-, Dél-, Délkelet-Ázsia, ezeken belül pedig Kína, India és az ASEAN országok, továbbá fentiekkel részben átfedésben a BRICS nemzetek.

A 21. század második évtizedében annak ellenére nem lesz könnyű feladat az ezekből a világrégiókból, regionális integrációkból, országcsoportokból való hallgatók toborzása, hogy elviekben és tényszerűen, a számok szintjén is a világ legnagyobb hallgatói migrációs kibocsátó térségei közé tartoznak. 


\section{Ázsiai (KÍNAi) HALlgatók MOBILitása}

\section{Az ázsiai hallgatókra ható mobilitási toló- és húzóeroók}

Annak megértéséhez, hogy mi okozza a világjárvány után a nemzetközi hallgatói mobilitásban résztvevő ázsiai, elsősorban kínai hallgatók létszámának potenciális csökkenését, illetve azt, hogy ezt a nem várt, de anticipált csökkenést miként lehet ellensúlyozni, röviden szükséges áttekinteni a hallgatók intézményválasztási motivációit.

Gong és Huybers (2015) a nemzetközi mobilitás mellett döntő hallgatókra, közöttük elsősorban a kínai hallgatókra vonatkoztatva megállapítják, hogy a nemzetközi hallgatói migrációra egyaránt hatnak toló- és húzó erők. Értelmezésükben a toló erők olyan a hallgató anyaországában felmerülő, a felsőoktatást érintő körülmények, amik a jelentkezőt a külföldi intézményválasztásra sarkallják, ezekre ennél fogva a hallgatót befogadni szándékozó országok nemigen tudnak hatást gyakorolni. Ezzel szemben a húzó faktorokat intézmény- és országspecifikus csoportokra osztják. Az Ausztráliában tanulmányokat folytató kelet-ázsiai, kifejezetten kínai hallgatók vonatkozásában azt állapítják meg, hogy amíg az intézményi „húzóerő", egyértelműen az egyetemi rangsorokon való megjelenés, addig az országválasztásban a biztonság, a brit egyetemekhez viszonyított alacsonyabb tandíjak és a relatíve gyors és akadálymentes vízumügyintézés voltak a döntő tényezők.

Egy 2015-ben 28 éve az Egyesült Királyságban élő, a Cambridge Egyetemen diplomát szerzett kínai hallgatótoborzó ügynök (Susan Fang), akit a British Council 2003-ban az év legjobb toborzó ügynökének szavazott, azt a tanácsot adta a kínai hallgatókat befogadni kívánó egyetemeknek, hogy

1. a kínai szülők a felsőoktatást megtérülő befektetésnek tekintik. A befektetés tárgya lehet tárgyiasult, azaz a kínai szülők szeretik, ha gyermekeik grandiózus, modern campusokon, kiemelkedő infrastrukturális körülmények között, kényelmes szállásokon élnek. A befektetés nem materiális oldalának a presztízsbe, az imázsba történő befektetést tekintik;

2. az egyetem nevét (brandjét) helyesen válasszák meg. A kínai szülők szeretik a nagyvárosi környezetet, ezért érdemes a városról vagy olyan értéket képviselő brandről elnevezni az egyetemet, ami az ,amerikai/nyugati álmot” közvetíti a szülők felé;

3. amíg a külföldi diplomaszerzés fő motivációja a jövedelemszerzés, a magasabb társadalmi pozíció megszerzése, addig a kínai hallgatók, a pénzügy, gazdálkodás és menedzsment, marketing, stb. jellegü gazdasági szakokat fogják választani. A jövedelemszint emelkedésével azonban a nem-materiális célok elérése is megfogalmazódik majd, így a felsőoktatási intézményeknek érdemes lesz a „,puhább”, pl. design, kreatív vállalkozásfejlesztés, nemzetközi fejlesztés, stb. szakokat is indítaniuk;

4. a rangsorokon való megjelenés elengedhetetlen. A rangsoroknak való „tisztelgés” a Han-dinasztia korára (i.e. 206 - i.sz. 220) vezethető vissza, ahol a birodalmi szolgálati vizsgarendszer a kínai ember intellektuális, társadalmi és politikai pozícióját egy életre meghatározta (Fang, 2015). 
Bodycott és Lai (2012) megállapítják, hogy a kínai hallgatók esetében a külföldön tanulásról szóló döntést nagymértékben a szülők hozzák, legalábbis a végső elhatározás családi konszenzuson alapul. 2012-ben a kínai családok még úgy látták, hogy az ország által kínált felsőoktatási lehetőségek korlátozottak, a külföldi diplomaszerzés által a gyerekek idegennyelv tudásra, valamint az anyaországba való visszatérés során jólfizető állások betöltéséhez szükséges kapcsolati hálóra tesznek szert. A külföldön tanult kínai hallgatók képzettségéről és társadalmi pozíciójáról kialakult kép kedvezőbb volt, mint a Kínában diplomát szerzettek megítélése. Fentieket az is erősítette, hogy a kínai diploma nemzetközi megítélését kedvezőtlenebbnek látták, mint a külföldiét. A kutatási mintába bevont kínai hallgatók válaszai alapján, további megállapításuk az, hogy a hallgatók 65 százalékának esetében az országválasztásról a hallgató döntött, magáról az egyetemről és a képzési programról, pedig a szülők.

Egy Hollandiába kínai hallgatókat toborzó ügynökség arra hívja fel a figyelmet, hogy Kínában az internetes keresőmotorok eltérnek az európai platformokról, ezért kiemelten fontos, hogy mandarin nyelven, a keresések 70 százalékát magáénak tudó Baidu-n keresztül hirdessenek az egyetemek. Megjegyzik, hogy a legelterjedtebb kínai közösségi portál a WeChat, így a 900 millió kínai felhasználó eléréséhez a legmegfelelőbb eszköznek tartják. Megjegyzik még, hogy a kínai hallgatótoborzásban a „branding” a kulcsszó, azaz a kínai családok kizárólag a presztízsért, az értékért hajlandóak pénzt áldozni, ezért a felsőoktatási intézmények minden áron presztízst kell, hogy közvetítsenek (Verot, 2020).

Ghazarian (2016) megállapítja, hogy a kínai családok számára a presztízs, az országimázs kiemelkedő, így az Amerikai Egyesült Államokban tanulni kívánó fiatalok esetében ez a legfontosabb döntő tényező. Amikor azonban egy ország (pl. Japán) a kínai hallgatók megítélése alapján nem képvisel Kínánál lényegesen magasabb imázst, akkor az olyan tényezők, mint a vízumszerzés lehetősége, földrajzi közelség, tandíjak mértéke és megélhetési költségek, valamint a célországban lévő családi és baráti kapcsolatok jóval nagyobb szerepet játszanak a döntésben.

Austin és Shen (2016) eredményei megerősítik a fentieket, ugyanakkor kutatásaik szerint a kínai hallgatók megítélése alapján - az amerikai egyetemek pozitív percepciója komplexebb a jó országimázsnál: az amerikai felsőoktatási intézményekről kialakult kedvező kép, a család támogatása, az Amerikai Egyesült Államok egyetemeinek rangsorokon betöltött pozíciója, az amerikai egyetemeken való tanulás által szerezhető versenyelőnyök, az amerikai munkaés letelepedés lehetősége együttesen befolyásolják az Amerikában folytatott felsőfokú tanulmányokról szóló döntést. Ugyanakkor valóban, a megkérdezett kínai hallgatók az Amerikai Egyesült Államokra a szabadság, a lehetőségek és a jólét országaként tekintenek.

Ping et al. (2020) az Amerikai Egyesült Államokban tanuló kínai hallgatókkal kapcsolatban megállapítják, hogy 20 százalékuk matematikát és informatikát, 19 százalékuk gazdálkodás és menedzsmentet, 18 százalékuk pedig egyéb műszaki tudományi területen való képzést választ. Kimondják, hogy ezek a hallgatók magas jövedelemszinttel rendelkező családokból származnak, megfeleltek a kínai egyetemi felvételi kritériumoknak, mégis Amerikában tanulnak tovább, aminek fő okát abban látják, hogy ezeken a területeken lehet Kínában magas béreket biztosító állásokat betölteni, ugyanakkor az amerikai képzések egyértelműen jobbak.

Fentieket erősítik meg a kínai Oktatási Minisztérium (Ministry of Education PRC, 2018) 
publikációi: felmérésük szerint a külföldön diplomát szerzett kínai hallgatók közel 84 százaléka hazatér.

2019-ben a QS Rankings is kiadott az egyetemek számára egy kínai hallgató toborzást segítő kiadványt, amiben felhívják a figyelmet arra, hogy a jelenleg külföldön tanuló 928.000 kínai hallgató sorrendben az Amerikai Egyesült Államokat, Ausztráliát, az Egyesült Királyságot, Kanadát és Új-Zélandot választja, felméréseik alapján azonban a sorrend a közeljövőben megváltozik: Ausztrália megelőzi majd az USA-t, Kína pedig Új-Zélandot. A QS megállapításai szerint a felsőoktatási intézmény brandje, reputációja és a kínai webfelületek és közösségi portálok megfelelő alkalmazása a sikeres toborzás titka (QS, 2019).

Az elmúlt néhány (világjárvány előtti években) világossá vált, hogy a kínai hallgatókért versenyző nem kínai egyetemek két alapvető oknál fogva egyre szorosabb versenyben állnak egymással: egyrészt növekszik a „piacra belépők száma”, másrészt maguk a kínai egyetemek is egyre nagyobb presztízst képviselnek, egyre magasabbra jutnak a világranglistákon. A Study International (2020) szerzői megjegyzik, hogy amíg a THE TOP10-es világranglistáját szinte megdönthetetlenül nyolc amerikai és két brit egyetem vezeti, a 2020-as év igazi nyertesei a kínai egyetemek voltak: a TOP100-ban háromról hatra kétszereződött a kínai egyetemek száma, összesen 20 kínai egyetem került a világ 1.500 legjobb egyetemét felsorakoztató listára, amik közül 19 javított az előző évhez viszonyított pozícióján, a Tsinghua Egyetem pedig „bejutott” a világ 20 legjobb felsőoktatási intézménye közé.

Kuroda et al. (2018) szerint a kínai egyetemek egyre rangosabbá válása nem a véletlen műve: Ázsiában a kilencvenes évek eleje óta szisztematikusan fejlesztik az oktatási rendszereket, aminek eredményei most kezdenek beérni. A felsőoktatás vonatkozásában úgy fogalmaznak, hogy Ázsia „elázsiaiasodik” vagy Kelet-Ázsia „elkeletázsiaiasodik”.

\section{Kinai hallgatók Közép-Európában}

Li (2020) megjegyzi, hogy az EU tizenegy országának az összes felsőoktatási intézménye rendelkezik nemzetköziesítési, nemzetközi mobilitási stratégiával, ami az EU 2012-es 13-as felhívására adott válasz, amiben az akadémiai autonómia elismerése és tiszteletben tartása mellett az Európai Felsőoktatási Térség országait komprehenzív nemzetköziesítési stratégia kidolgozására ösztönzik. Az Európai Bizottság kutatását idézve állapítja meg, hogy Magyarországot a nemzetközi hallgatók a felsőoktatás magas színvonala, a más kultúrák megismerésének motivációja, és az alacsony ön- és megélhetőségi költségek mentén választják. Elismeri Magyarország Kormányának Kína-barát törekvéseit, valamint a Stipendium Hungaricum program erőfeszítéseit, amit a magyar felsőoktatási intézmények nemzetköziesítésének alapjának tart. Másodelemzésekre hivatkozva megállapítja, hogy a Magyarországra érkező kínai hallgatók motivációik és hátterük alapján feltételezhetően hasonlítanak az Oroszországot választó kínai hallgatókra, akik alacsony jövedelmű, első generációs családok kevésbé jó tanuló gyermekei, akiknek angol nyelvismerete szintén nem magas színvonalú. 


\section{A kinai hallgatók világjárvány utáni választásai}

Xiong et al. (2020) kínai és hongkong-i hallgatókat kérdeztek meg a pandémia utáni intézményválasztási döntéseikről. Megállapítják, hogy a világjárvány előtt a „hagyományos” tolóés húzó erők hatottak a hallgatókra. A toló erők között a minőségi felsőoktatás hiányát, a versenyképesség növelésének nehézségeit, illetve a gazdasági és társadalmi viszonyokat emelték ki; a húzó erők között, pedig

1. a célországban megszerezhető diploma elismertségét,

2. a barátok-ismerősök és különösen a szülők referenciáit,

3. a költségeket, amik nemcsak a tandijjakat és a megélhetési költségeket, hanem a biztonság költségét is tartalmazták,

4. a környezeti tényezőket (beleértve az éghajlati viszonyokat),

5. a Kínához való fizikai közelséget, ill. azt, hogy

6. a célterületen lakik-e már ismerős vagy családtag.

A 2.312 fós minta alapján azt a következtetést vonták le, hogy a hallgatók 84 százaléka nem kíván külföldön tanulni a Covid-19 után. (A megkérdezettek 71 százaléka 18-25 éves, első diploma megszerzése előtt álló kínai hallgató volt.) Az általuk felvett minta alapján a legnépszerűbb célországok is megváltoznak majd: az Amerikai Egyesült Államokat Hongkong, az Egyesült Királyság, Japán és Tajvan követi majd. Legkiemelkedőbb megállapításuk az, hogy a Kínából (Hongkongból) külföldön tanulni kívánó hallgatók egyharmada a térségben marad majd. A kutatásnak nemcsak az az egyik érdekessége, hogy Ausztrália, Kanada és ÚjZéland, három angol anyanyelvű ország kiesett a hallgatók TOP5 preferenciája közül, hanem az is, hogy Franciaország, Korea, Olaszország, Malajzia és Makaó a legkevésbé népszerű országokká váltak. A szerzők arra a következtetésre jutnak, hogy a térségből kiáramló hallgatói mobilitás nem csökken, de irányt vált, a hallgatók a régió „,biztonságos” országaiban maradnak, megállapítják továbbá, hogy az ázsiai-csendes-óceáni térség új felsőoktatási „normája” az együttműködés, a regionalizmus lesz.

Az Economist Intelligence Unit (2020) felmérései hasonló következtetésekre jutnak. Megállapítják, hogy a világjárvány következtében, rövidtávon valószínűleg csökkeni fog a kínai hallgatók külföldön való továbbtanulás iránti érdeklődése. A mobilitást egyrészt az utazási korlátozások fogják akadályozni, másrészt a vírustól való félelem, a személyes biztonság érzetének hiánya is. Ez a csökkenés azonban a külföldi diplomák magas presztízse miatt inkább halasztást, mint érdekfogyást okoz. Eredményeik szerint a kínai jelentkezők létszámát illetően az USA és Ausztrália veszíteni fognak, míg néhány európai és ázsiai ország nyertesen kerülhet ki a helyzetből. Megállapításaik szerint a csökkenő költségek és a növekvő bizonytalanság miatt az on-line módon, távoktatási formában szerzett diplomák kerülnek majd előtérbe. 2020ban a kínai egyetemek külföldi felsőoktatási intézményekkel 2.300 közös képzési programot működtettek, a szerzők feltételezik, hogy ezek népszerűsége azért növekszik majd, mert a több egyetemre egyszerre beiratkozott hallgató azt reméli, hogy a járvány ellenére hozzájut okleveléhez. Japán és Szingapúr valószínűleg nyertese lesz az Egyesült Államok és Ausztrália iránti érdeklődés visszaesésének. Az amerikai-kínai konfliktusból a brit egyetemek 2017 óta egyértelműen nyertesen kerültek ki, részben azáltal, hogy egyrészt a végzett hallgatók számá- 
ra munkavállalási vízumot vezettek be, másrészt számos egy éves mesterképzést indítottak. A szerzők megállapítják, hogy a kínai hallgatókért nagy „harc” indul a világ felsőoktatási intézményei között. Azokban az országokban, ahol a járványt nem tudták megállítani, a felsőoktatási intézmények különös kedvezményeket kell, hogy biztosítsanak. A szerzők javasolják az önköltségek és a felvételi követelmények csökkentését, a képzések „,testre szabását”, illetve a kínai gazdaságpolitika prioritásait figyelembe vevő szakok (informatika, mikroelektronika) indítását.

\section{Nemzetközi (kinai) hallgatók Magyarországon}

Hazánkban jelenleg a nemzetközi hallgatók származási országonkénti TOP10 listáját a német hallgatók vezetik, őket követi a kínai, a román állampolgárságú, az iráni, a szerb és szlovák állampolgárságú, valamint az ukrán állampolgárságú, a török, a nigériai valamint a norvég hallgatói közösség. A fent felsoroltak közül a legnagyobb nemzetközi hallgatói országcsoport (német) 3.500 fó feletti létszámot, a legkisebb (norvég) nagyságrendileg 1.000 főt képvisel (Oktatási Hivatal, 2018).

Fentiekből megállapítható, hogy nemcsak az egyes intézmények szintjén, hanem a hazai felsőoktatás egészére igaz, hogy a határon túli (erdélyi, partiumi, újvidéki, felvidéki, kárpátaljai) magyarok az anyaország nemzetköziesítésében kiemelt hallgatói létszámokat képviselnek.

A nemzetközi hallgatók Magyarországon elsősorban az orvos-, a fogorvos- és állatorvos képzéseket választják (Eduline.hu, 2017). A 2019/20-as tanévben, hazánkban tanuló 38.422 nemzetközi hallgató többsége Budapesten, Debrecenben, Szegeden és Pécsett tanult (HRportal.hu, 2020).

A magyarországi egyetemvárosok mindent megtesznek az egyes prioritást élvező küldő országokból való hallgatói közösségek kialakítása érdekében. A Kína melletti elkötelezettség egyik eszköze a Konfuciusz Intézetek (KI) létrehozása, amelyek közül az első 2006-ban az ELTE-n (Budapest) nyitotta meg kapuit, amit a Szegedi Tudományegyetemen (2012), a Miskolci Egyetemen (2013) és a Pécsi Tudományegyetemen (2015) nyílt intézetek követtek (Tarrósy és Vörös, 2020). Budapesten 2004 óta kéttannyelvű kínai-magyar általános és középiskola (Magyar-Kínai Két Tanítási Nyelvű Általános Iskola és Gimnázium) is működik.

A budapesti kéttannyelvű általános és középiskola elődje a szintén Budapesten 1998-ban alapított Guang Hua nyelviskola volt (Ázsiamánia, 2020), amit a harbini származású, 1991ben Magyarországon letelepedett Zhang Quingbin hozott létre, aki a Hagyományos Kínai Orvoslás Magyarországi Egyesületének elnöke, aki a Semmelweis Egyetem Általános Orvostudományi Karának Családorvosi Tanszékének is előadója (Hagyományos Kínai Orvoslás Egyesülete, 2021; Semmelweis Egyetem, Általános Orvostudományi Kar, Családorvosi Tanszék, 2021).

A budapesti Semmelweis Egyetem (SE) Egészségtudományi Kara 2009 óta tart fenn kapcsolatokat a Heilongjiang Kínai Orvostudományi Egyetemmel. A hagyományos kínai gyógyászat BSc képzés egyedülálló hazánkban, mert a hallgatók az első 4 év során Budapesten, az utolsó évben pedig Harbinban, a Heilongjiang Kínai Orvostudományi Egyetemen sajátítják el a kínai gyógyászat tudományát. A programot sikeresen elvégzők a harbini egyetem BSc 
diplomáját kapják kézhez, amelyet Magyarországon honosíttathatnak (Semmelweis Egyetem, Egészségtudományi Kar, 2021). A Pécsen 2015-ben megalakított Konfuciusz Intézet szintén a hagyományos kínai orvoslásra fókuszál, az Egészségtudományi Kar keretei között törekszik a tradicionális kínai medicina megismertetésére és oktatására (Pécsi Tudományegyetem, Egészségtudományi Kar, 2021).

2019 óta a Budapesti Corvinus Egyetem (BCA) is rendelkezik egy olyan kettős MBA-képzéssel, melyet - a Magyar Nemzeti Bank támogatásával - a sanghaji Fudan Egyetemmel hoztak létre (Budapesti Corvinus Egyetem, 2019). A nagy presztízsű intézmény, ami a QS világrangsorán a 34., a THE listáján pedig a 70. helyet tölti be, szintén a Magyar Nemzeti Bank támogatásával, az Innovációs és Technológiai Minisztériummal 2019 decemberében új budapesti campus létrehozásáról döntött, ill. kötött együttműködési megállapodást (Fudan University, 2019). A várhatóan 2024-re megvalósuló új campus felépüléséig négy budapesti egyetemmel (BCE, BME, ELTE, SE) hoz létre további kettős képzési programokat a sanghaji intézmény (Növekedés.hu, 2020).

Nehéz megbecsülni a Magyarországon élő kínaiak pontos számát, a Bevándorlási és Munkaügyi Hivatal (BMH) 2019-es adatközlése alapján a 2013 és 2017 között kibocsátott letelepedési kötvénnyel 59 ország 19.838 polgára érkezett, akik közül 15.751-en, azaz több mint 80 százalékban voltak kínaiak (Wiedemann, 2019). A KSH adatszolgáltatása alapján 2020-ban 28.779 ázsiai állampolgár tartózkodott hazánkban, akik közül 9.909-en rendelkeztek kínai állampolgársággal (KSH, 2021). 2020-as becslések alapján egy 30.000 főből álló kínai közösség él Budapesten, Kőbányán, a környéket a magyar főváros kínai negyedének is nevezik, ami Közép-Európában a legnagyobb lélekszámúnak számít. A közösség 50.000 fővel a kilencvenes években élte fénykorát, mivel 1989-1992 között kínai állampolgároknak nem volt vízumra szükségük a Magyarországra történő beutazáshoz. Azóta sokan hazatértek, vagy Nyugat-Európa országaiba települtek (Offbeat, 2021). A budapesti kínai negyed (Monori Center) becslései megerősítik a kínai közösség jelenlegi 30.000 fős létszámát, megjegyzik, hogy a hazánkban tartózkodó kínaiak döntő többsége Budapesten él (Monori Center, 2021).

\section{NemZetKÖZIEsítés, ÁZSIAI/KÍNAI HALlGATÓI KÖZÖSSÉGÉPÍTÉS GYÖRBEN}

Fentiek alapján felmerül a kérdés, hogy milyen eszközökkel toboroz egy nem fővárosi egyetem olyan ázsiai, elsősorban kínai hallgatókat, akik számára a fogadó országban jelenlévő anyaországból származó közösség (családi, baráti kötelékek) kiemelten fontosak?

Mivel a közösséghez tartozáson kívül a presztízs az, ami az egyetemválasztáskor a kínai családokat leginkább befolyásolja, a Széchenyi István Egyetem az alábbi kiemelt eszközökkel törekszik a nemzetközi hallgató felé presztízsértékű, minőségi képzéseit közvetíteni:

- Rangsorokon történő megjelenés;

- Branding (kiemelkedő ipari kapcsolatok, különösen az Audi Hungária Motor Zrt.vel);

- Képzések nemzetközi akkreditációja;

- Impozáns, grandiózus infrastrukturális fejlesztések. 
Fentieket figyelembe véve, a Széchenyi István Egyetem 2018 februárjában regisztrálta magát, hogy megmérettessen a QS World University Rankings (WUR) rangsorában, majd 2018 októberében, a 2019-es regionális listák publikálásakor, az EECA regionális csoport 201-250. helyei között jelent meg. A QS EECA University Rankings 2020-as listáján az egyetem a 201-210. helyen, 2020-ban pedig a 2021-re vonatkozó adatok megjelenésekor 28 helyet lépett előre, a 173. helyen rangsorolt.

A Széchenyi István Egyetem 2020-ban a Times Higher Education (THE) által 2019-ben létrehozott listán, az Impact Ranking-en is megmérettette magát. A rangsor a felsőoktatási intézmények tudásötszög (quintuple helix) modelljében való megfelelését, a társadalmi és gazdasági szerepvállalását méri, a mérőszámokat az ENSZ Fenntartható Fejlődési Céljaihoz (United Nations' Sustainable Development Goals (SDGs)) köti. A 17. cél minden regisztráló felsőoktatási intézmény számára kötelező elem, másik három fenntarthatósági cél pedig kötelezően választandó.

A Széchenyi István Egyetem a következő négy kategóriát választotta:

- SDG 4-Oktatás minősége;

- SDG 8 - Tisztességes munka és munkavégzés, gazdasági növekedés;

- SDG 9 - Ipar, Innováció, Infrastruktúra;

- SDG 17 - Partnerség a célok megvalósítására.

Összességében 600+ helyezést elérve, a Tisztességes munka és munkavégzés, gazdasági növekedés kategóriában (SDG8) a világ kétszáz legjobb felsőoktatási intézménye közé sorolták.

A Széchenyi István Egyetem már a nemzetközi hallgatók fogadását megelőzően is - az akadémiai oldalon végbement curriculum reformmal párhuzamosan - óriási erőfeszítéseket fordított az infrastrukturális fejlesztésekhez szükséges források bevonására, a létesítmények megvalósítására. Ezek keretében épültek kollégiumi épületek, a Közgazdaságtudományi Kart és a Menedzsment Campus Kompetencia Központot befogadó tanulmányi és vállalkozásfejlesztési egység, sportpályák és egyéb szabadidős létesítmények, vendéglátóipari egységek. Fenti fejlesztések eredményeként 2019-ben kétszer annyi szavazattal, mint a második helyen szereplő felsőoktatási intézmény, az egyetem elnyerte a Magyarország legszebb campusa címet (Eduline.hu, 2019).

Az Audi Hungaria Zrt.-vel fenntartott ipari kapcsolatok a vállalat győri letelepülése, azaz 1993 óta meghatározóak az egyetem számára. Az Audival való közel harminc éves, minden területre kiterjedő, szerves együttműködést leginkább a nemzetközi hallgatók 2020-as minőségbiztosítási kérdéseire adott egyik válasz foglalja össze leginkább, ami szerint a hallgatók büszkék arra, hogy olyan városban és egyetemen tanulhatnak, ahol „mindenütt megjelenik a négy karika".

A nemzetközi hallgatók toborzását a Széchenyi István Egyetem közel ezer vállalattal fenntartott, gyakornoki pozíciókat is felajánló kapcsolati hálója támogatja. A kínai hallgatók toborzása szempontjából kiemelten fontos a felsőoktatási intézménynek Kína egyik technológiai óriásvállalatával 2015-ben kötött együttműködése, aminek értelmében a Huawei labor- és eszközfejlesztéssel támogatta az egyetemet, s az együttműködés emellett hallgatók, oktatók bevonására és közös kutatás-fejlesztési programokra is kiterjedt. 2020-ban a válla- 
lat 20 éves európai és 15 éves magyarországi jelenlétének jubileumán a felek kibővítették a megállapodást, aminek keretében a Huawei ingyenesen elérhetővé teszi angol nyelvű képzési programjait az egyetem magyar és nemzetközi hallgatói számára, akik a vállalat által biztosított infrastruktúrát használva speciális, világszínvonalú tudást szerezhetnek (Széchenyi István Egyetem, 2020b).

A szakok nemzetközi akkreditációja további presztízs értéket közvetít a nemzetközi hallgatók számára. 2020-ban a Széchenyi István Egyetem angol nyelvű MBA programja, a Magyar Nemzeti Bank támogatásával kettős képzésben indult el a University of Rhode Island (Kingston, Amerikai Egyesült Államok) felsőoktatási intézményével. A képzés AACSB akkreditált. Az amerikai minősítő intézményt 1916-ban hozták létre, 2019-ben 800 felsőoktatási intézmény alap- és mesterszintü üzleti képzése rendelkezett a világ legszigorúbb és legismertebb akkreditációs intézményének engedélyével. A minősített programok 75 százaléka az Amerikai Egyesült Államokban, a fennmaradó 25 százalék döntő többsége pedig az Egyesült Királyságban, Franciaországban és Kanadában indult, ezért a Széchenyi István Egyetem és az URI kettős képzése nem csak közép-európai sztenderdek mentén mérve számít egyedinek (U2B Staff, 2020).

A Széchenyi István Egyetem legújabb és legkiemelkedőbb vállalása az egyetemi campustól 500 méterre a 3,6 hektáros területen épülő Technológiai és Innovációs Parkja (Science Park). A park összekapcsolja az infrastruktúrafejlesztési, a képzési, a vállalati kapcsolattartási, nemzetközi szolgáltató központi (éttermek, professzori vendégszállások, Campus 2) és az innovációs tevékenységet, integrálja mindazt, amit a felsőoktatási intézmény presztízsértékkel hoz létre, és a nemzetközi hallgató toborzó tevékenysége során is alkalmaz.

A Széchenyi István Egyetemre beiratkozó nemzetközi hallgatók, közöttük a kínai hallgatók is, nemcsak turisztikai céllal és eszközökkel érik el Európát: a felsőoktatási intézmény az Európai Bizottság által 2019-ben első alkalommal kiírt, közös európai campus létrehozását célzó pályázathoz 2020-ban az alábbi partnerintézményekkel csatlakozott: IP Leiria (Portugália), IPCA (Portugália), Athlone University of Technology (Írország), University of Limerick (Írország), Häme University of Applied Sciences (Finnország), NHL Stenden (Hollandia), FH University of Voralberg (Ausztria).

A RUN (Regional University Network) elnevezésű nyertes hálózat fő céljai a közös képzési programok megvalósítása, a hallgatói és oktatói mobilitás, valamint a kutatási tevékenység ösztönzése. A Széchenyi István Egyetem a Leuveni Nyilatkozatban megfogalmazott céloknak megfelelően a külföldi részképzésben, vagy szakmai gyakorlaton legalább három hónapig résztvevő hallgatók teljes hallgatói létszámon belüli arányát kívánja 20 százalékra emelni, aminek eredményeként nemcsak a magyar, de az intézmény nemzetközi hallgatói is lehetőséget kapnak a nyolc felsőoktatási intézmény képzésein való részvételre, európai mobilitásra. 


\section{KÖVETKEZTETÉSEK}

A hazai felsőoktatási intézmények nemzetköziesítési stratégiájuk megfogalmazásakor a világgazdasági trendekkel összhangban, a „keleti nyitás” gazdaságpolitikájához alkalmazkodtak, azaz angol nyelvű képzéseiken elsősorban az ázsiai - főként kínai - hallgatók toborzására összpontosítottak. A kínai hallgatók az orvos, fogorvos és állatorvos képzéseken koncentrálódó német hallgatók mellett a második legnagyobb nemzetközi hallgatói közösséget jelentik Magyarországon, azonban a járvány után egyrészt az ázsiai, ezen belül a kínai felsőoktatási rendszerek látványos fejlődése, valamint az egyes ázsiai gazdaságok igen fegyelmezett járványkezelésének következtében az ebből a térségből származó hallgatók megnyeréséért egyre nagyobb erőfeszitéseket szükséges tenniük a felsőoktatási intézményeknek. Az angol anyanyelvű országok, illetve a nem angol anyanyelvủ országok fővárosai, illetve nagy nemzetközi hallgatói közösséggel rendelkező nem fővárosi egyetemei által teremtett versenyben az egyes intézményeknek szükséges megtalálniuk saját nemzetköziesítési modelljüket, azt a kínálatot, ami a mobilitásban résztvevő hallgató és családja szerint presztízsértékkel bír. A Széchenyi István Egyetem válság utáni „eszköztára” a nemzetközi rangsorokon való egyre inkább javuló pozíciójára, a felsőoktatási intézmény - 1993 óta Győrben jelenlévő Audi Hungaria Zrt. által is meghatározott - brandjére, angol nyelvű képzéseinek nemzetközi akkreditációjára, valamint impozáns, grandiózus infrastrukturális beruházásaira épít, melyek közül legújabb vállalása a Technológiai és Innovációs Parkja. Ezen törekvése nemcsak a felsőoktatási intézmény három misszióját (oktatás, kutatás, ipari-társadalmi kapcsolatok) egyesíti, hanem szimbolizálja azt is, hogy a huszonegyedik századi felsőoktatási intézményekben végzett hallgatóknak a globális értékláncok által teremtett munkaerőpiaci környezetben szükséges helytállniuk, illetve a közép-kelet-európai gazdaságok gerincét adó kis- és középvállalkozásoknak is lehetőségük van a világvállalatok által dominált gazdasági környezetbe bekapcsolódniuk. Az Egyetem egyszerre funkcionál nemzetközi vállalati, kutatási és felsőoktatási egységként, és mint ilyen, vonzó lehet a legfejlettebb nemzetgazdasági környezetből érkező hallgatók számára is.

\section{FELHaSZnÁlt irodalom}

Austin, Larry - Libi Shen (2016): Factors Influencing Chinese Students' Decisions to Study in the United States, Journal of International Students, Vol. 6, No. 3, p. 722-739, https://www.ojed.org/index.php/jis/article/view/353, Letöltés: 2021. 01. 03.

Ázsiamánia (2020): Budapest Guang Hua Kínai Nyelvű Iskola, https://asiamania.hu/ceg-adatlap/18, Letöltés: 2021.01 .16$.

Bodycott, Peter - Ada Lai (2012): The role of Chinese parents in decisions about overseas study, University World News, 5 August 2012, https://www.universityworldnews.com/post.php?story=20120731122209685, Letöltés: 2021.01.03.

Budapesti Corvinus Egyetem (2019): Együttműködés a Fudan Egyetemmel, https://www.uni-corvinus.hu/hir/ egyuttmukodes-a-fudan-egyetemmel/

Carayannis, Elias G. - Thorsten D. Barth - David F. J. Campbell (2012): The Quintuple Helix innovation model: global warming as a challenge and driver for innovation, fournal of Innovation and Entrepreneurship, Vol. 1, No. 2, pp. 1-12, https://doi.org/10.1186/2192-5372-1-2, Letöltés: 2021. 01. 01.

Economist Intelligence Unit (2020): How will the coronavirus affect outbound Chinese students?, https://www.eiu. 
$\mathrm{com} / \mathrm{n} /$ how-will-the-coronavirus-affect-outbound-chinese-students/, Letöltés: 2021. 01. 03.

Eduline.hu (2017): Ezekre a magyar egyetemekre érkezik a legtöbb külföldi hallgató, 2017. október 4., https://eduline.hu/felsooktatas/kulfoldi_hallgatok_szama_no_HV2BU4, Letöltés: 2021. 01. 10.

Eduline.hu (2019): Melyik az ország legszebb campusa? A második körben a győri egyetem kapta a legtöbb szavazatot, 2019. április 1., https://eduline.hu/campus_life/20190401_legszebb_egyetemi_campus_szavazas_vegeredmenye, Letöltés: 2021. 01. 17.

Fang, Susan (2015): How to attract Chinese students: four tips for overseas universities, The PIE Blog, 11 December 2015, https://blog.thepienews.com/2015/12/how-to-attract-chinese-students-four-tips-for-overseas-universities/, Letöltés: 2021. 01. 02.

Fudan University (2019): Fudan signs MOU to establish new campus in Budapest, https://www.fudan.edu.cn/ en/2019/1224/c1092a103653/page.htm

Ghazarian, Peter G. (2016): Country Image and the Study Abroad Destination Choice of Students from Mainland China, fournal of International Students, Vol. 6, No. 3, pp. 700-711, https://www.ojed.org/index.php/jis/article/ view/350, Letöltés: 2021. 01. 03.

Gong, Xue - Twan Huybers (2015): Chinese students and higher education destinations: Findings from a choice experiment, Australian Journal of Education, Vol. 59, No. 2, pp. 196-218, https://doi.org/10.1177/0004944115584482, Letöltés: 2021. 01.02.

Hagyományos Kínai Orvoslás Magyarországi Egyesülete (2021): Vezetőség, https://www.hkome.hu/vezetsg, Letöltés: 2021.01. 16.

HRportal.hu (2020): Több ezer munkahelyet teremt hazánkban a külföldi hallgatók jelenléte, 2020. október 2., https://www.hrportal.hu/hr/tobb-ezer-munkahelyet-teremt-hazankban-a-kulfoldi-hallgatok-jelenlete-20201002. html, Letöltés: 2021. 01. 10.

Keczer Gabriella (2020): Felsőoktatási-irányítási és egyetemi kormányzási trendek Európában, Educatio, Vol. 29, No. 1, pp. 48-63, https://doi.org/10.1556/2063.29.2020.1.4, Letöltés: 2021. 01. 31.

Kováts Gergely (2020): Menedzserizmus a felsőoktatásban: érvek, ellenérvek, alternatívák, Educatio, Vol. 29, No. 1, pp. 3-18, https://doi.org/10.1556/2063.29.2020.1.1, Letöltés: 2021. 01. 31.

KSH (2021): Magyarországon tartózkodó külföldi állampolgárok földrészek, országok és nemek szerint, január 1. (1995-), https://www.ksh.hu/docs/hun/xstadat/xstadat_eves/i_wnvn001b.html, Letöltés: 2021. 01. 17.

Kuroda, Kazuo - Miki Sugimura - Yuto Kitamura - Sarah Asada (2018): Internationalization of Higher Education and Student Mobility in Fapan and Asia. Paper commissioned for the 2019 Global Education Monitoring Report, Migration, displacement and education: Building bridges, not walls, https://unesdoc.unesco.org/ark:/48223/ pf0000266196, Letöltés: 2021. 01. 03.

Li, Xueyan (2020): Chinese Students Choosing Hungarian Tertiary Education: a Systematic Review, East Asia: An International Quarterly, Vol. 37, No. 4, pp. 317-330, https://doi.org/10.1007/s12140-020-09333-y, Letöltés: 2021. 01. 03 .

Lukács Eszter -Kovács Zsolt -Völgyi Katalin - Filep Bálint (2020): A „keleti nyitás” politika szerepe a magyar felsőoktatás és a Széchenyi István Egyetem nemzetköziesítésében, Külügyi Szemle, Vol. 19, No. 1, pp. 80-104.

Ministry of Education PRC (2018): 2017 sees increase in Chinese students studying abroad and returning after overseas studies, http://en.moe.gov.cn/News/Top_News/201804/t20180404_332354.html, Letöltés: 2021. 01.03.

Monori Center (2021): Chinatown Budapest - Kínai Negyed, https://monoricenter.hu/monori-center/, Letöltés: 2021. 01.17.

Növekedés.hu (2020): A sanghaji Fudan Egyetem első Kínán kívüli campusa már 2024-ben megnyílhat Budapesten, 2020. szeptember 16., https://novekedes.hu/hirek/a-sanghaji-fudan-egyetem-elso-kinan-kivuli-campusa-mar-2024-ben-megnyilhat-budapesten, Letöltés: 2021. 01. 17.

Offbeat (2021): The Chinese Community in Budapest, https://www.offbeatbudapest.com/budapest-city-guide/chinatown-budapest-restaurants/, Letöltés: 2021. 01. 17.

Oktatási Hivatal (2018): Felsőoktatási statisztikák, https://www.oktatas.hu/felsooktatas/kozerdeku_adatok/felsooktatasi_adatok_kozzetetele/felsooktatasi_statisztikak, Letöltés: 2021.01. 10.

Pécsi Tudományegyetem, Egészségtudományi Kar (2021): Hagyományos Kínai Orvoslás Konfuciusz Intézete, http://konfuciusz.etk.pte.hu/, Letöltés: 2021. 01. 16. 
Ping, Yanni - Chiang-nan Chao - Yingchuan Wang - Frankie Changli Wang (2020): The Chinese Students' Motivations for their Higher Education in the U.S., Fournal of Administrative Sciences and Policy Studies, Vol. 8, No. 1, pp. 1-9, https://doi.org/10.15640/jasps.v8nla1, Letöltés: 2021. 01. 03.

Pruvot, E. Bennetot -Thomas Estermann (2018): University Governance: Autonomy, Structures and Inclusiveness. In: Curaj, Adrian - Ligia, Deca - Remus, Pricopie (eds.): European Higher Education Area: The Impact of Past and Future Policies. pp. 619-638, Springer, Cham. https://doi.org/10.1007/978-3-319-77407-7_37

QS (2019): Recruiting Chinese Students: A Guide for International Student Recruitment, http://info.qs.com/ rs/335-VIN-535/images/Recruiting-Chinese-Students.pdf, Letöltés: 2021. 01. 03.

Semmelweis Egyetem, Egészségtudományi Kar (2021): Hagyományos Kínai Gyógyász (BSc), https://semmelweis. hu/etk/oktatas/hagyomanyos-kinai-gyogyaszat/, Letöltés: 2021. 01. 16.

Semmelweis Egyetem, Általános Orvostudományi Kar, Családorvosi Tanszék (2021): Előadók, https://semmelweis. hu/csot/oktatas/integrativ-medicina/eloadasok-2/posztgradualis-hagyomanyos-kinai-orvoslas-kepzes/eloadok/, Letöltés: 2021. 01. 16.

Study International (2020): More Chinese universities climb up world university rankings, https://www.studyinternational.com/news/chinese-universities-world-university-rankings/, Letöltés: 2021. 01. 03.

Széchenyi István Egyetem (2020a): Megtartotta alakuló ülését a Széchenyi István Egyetemért Alapítvány Kuratóriuma, 2020. július 23., https://uni.sze.hu/megtartotta-alakulo-uleset-a-szechenyi-istvan-egyetemert-alapitvany-kuratoriuma, Letöltés: 2021. január 1.

Széchenyi István Egyetem (2020b): A techóriás Huawei a Széchenyi István Egyetem szoros partnere, 2020. október 29., https://uni.sze.hu/a-techorias-huawei-a-szechenyi-istvan-egyetem-szoros-partnere, Letöltés: 2021. 01.17.

Tarrósy István - Vörös Zoltán (2019): Kinnai-magyar együttmüködés a felsöoktatásban és a kutatásban: Hetven év áttekintése a kétoldalú diplomáciai kapcsolatok fényében, In: Goreczky Péter (szerk.): Magyarország és Kína: 70 éves kapcsolat a változó világban, Külügyi és Külgazdasági Intézet, Budapest, pp. 196-213, https://kki.hu/wp-content/uploads/2020/01/K\%C3\%ADna_Magyarorsz\%C3\%Alg_70_online_HU.pdf, Letöltés: 2021. 01. 16.

The Economist (2020): The absent student, 8 August 2020, https://www.economist.com/leaders/2020/08/08/ covid-19-will-be-painful-for-universities-but-also-bring-change, Letöltés: 2021. 01. 31.

U2B Staff(2020): AACSB accredited MBAs: Are they worth the cost?, 24June 2020, https://u2b.com/2020/06/24/ aacsb-accredited-mbas-are-they-worth-the-cost/, Letöltés: 2021. 01. 17.

Verot, Olivier (2020): Social Media Strategies to Attract Chinese Students, https://nealschaffer.com/attract-students-from-china-social-media-strategies/, Letöltés: 2021. 01. 03.

Wiedemann Tamás (2019): 59 országból jött Magyarországra a húszezer letelepedési kötvényes, 2019. január 16., https://g7.hu/kozelet/20190116/59-orszagbol-jott-magyarorszagra-a-huszezer-letelepedesi-kotvenyes/, Letöltés: 2021.01. 17.

Xiong, Weiyan - Ka Ho Mok - Guoguo Ke - Joyce Oi Wun Cheung (2020): Impact of COVID-19 Pandemic on International Higher Education and Student Mobility: Student Perspectives from Mainland China and Hong Kong, Centre for Global Higher Education working paper series, Working paper No. 54, September 2020, https://www.researchcghe. org/perch/resources/publications/wp54to-publish.pdf, Letöltés: 2021. 01.03. 